MH Hadkiegészitő, Felkészitő és Kiképző Parancsnokság

\title{
A testnevelés és a sport szerepe a katonák felkészítésében
}

\author{
Dr. Eleki Zoltán ezredes, PhD
}

Kulcsszavak: testnevelés, sport, katonai felkészités, egészség megörzés, csapatépités

A sport történelmi szerepe a katonák felkészítésében vitathatatlan. Az edzett katona mindig nagyobb túlélő képességgel rendelkezett, ugyanakkor az egyetemes sport is gazdagodott a katonai felhasználás által. Új sportok születtek, ami leginkább a csapatsportok fejlödésében figyelhető meg. A sport a fizikai erőnlét fejlesztése mellett fontos az egészség megőrzés, a csapatépítés, a stresszoldás, a megtartó erö és a toborzás szempontjából is.

Napjainkban a technikai fejlödésének köszönhetően egyre inkább háttérbe szorul a napi tevékenységekhez kötődő testmozgás, a társadalom általános fizikai állapota fokozatosan romlik, nő az elhízottak aránya. Ez a jelenség megnehezíti a katonák fizikai felkészítését. A Magyar Honvédségben a fizikai felkészítés egy összetett rendszert alkot, magában foglalva az éves követelményrendszert, a testnevelési kiképzést, a sportversenyeket, a rekreációt és a Honvéd Testalkati Programot.

A testnevelés és sport kiváló eszköz a katonák felkészültségének növelésére, illetve a társadalom számára történő bemutatására, az egészség megőrzésére, ezáltal az állomány toborzásának és megtartásának támogatására.

A katonai szolgálat szempontjából fontos fizikai képességek kialakítása egyben a katona testi és lelki egészségét is pozitívan befolyásolja. Ebben a sport eszköze nagy segítséget jelent, ami hozzájárul az egészséges életmód, ezen belül a rendszeres testmozgás kialakításához és fenntartásához.

A jelenkor negatív tapasztalata, hogy a katonának jelentkező fiatalok fizikai teljesítő képessége évről-évre romlik, a civilizációs vívmányoknak köszönhetően a mindennapi fizikai aktivitási kényszer csökken. A mozgásszegény életmód az egészségi állapotra is negatívan hat. Ma a sport már nemcsak választható szórakozási forma, vagy foglalkozás, hanem minden ember elemi szükséglete, ha minél hosszabb ideig szeretné megőrizni egészségét és jó közérzetét. 
A társadalmi körülmények a katonákra is hatnak, így az eredményes fizikai felkészítéshez is egyre nagyobb erőfeszítésre van szükség. A testnevelés kiképzés önmagában nem elegendő, hatásosságához elengedhetetlen, hogy a katonák szabadidőjükben is sportoljanak, illetve szükség van olyan edzéslehetőségekre, versenyekre, ami ösztönzőleg hat rájuk.

\section{Mi a sport?}

A sport katonai felkészítésben betöltött szerepének vizsgálata előtt fontos értelmezni, hogy mit is jelent a sport napjainkban. Az alábbi három megfogalmazás mértékadó forrásoktól származik.

1. „Meghatározott szabályok szerint, időtöltésként vagy versenyszerüen folytatott testedzés" [1].

2. „Mindazon szervezett és/vagy szervezetlen, csoportos vagy egyéni testedzési tevékenységek gyüjtőfogalma, amelyekben az ember biológiai mozgásigényét, szükségletét, társadalmi körülmények között kielégíti” [2].

3. „A sport minden olyan fizikai tevékenység, amelynek célja esetenként vagy szervezett formában a fizikai és szellemi erőnlét kifejezése vagy fejlesztése, társadalmi kapcsolatok teremtése vagy különböző szintü versenyeken eredmények elérése" [3].

A megfogalmazások alapján megállapítható, hogy a sport fogalmát egyértelmüen definiálni nehéz, de olyan kifejezések mentén, mint a testedzés, a fizikai és szellemi erőnlét fejlesztése és kifejezése, a verseny, az eredmény és a társadalmi kapcsolatok, jól körülírható. Azt is fontos leszögezni, hogy a sport egy dinamikusan fejlődő jelenség, elég, ha csak a napjainkban egyre népszerübb E-sportra gondolunk, ami alapjaiban érintheti a sportról alkotott felfogást.

\section{A hadviselés és a sport kapcsolata a történelemben}

A hadviselés és a sport kölcsönhatása a történelemben jól megfigyelhetö. Az első sporttevékenység a vadászatra és a harcra való felkészülésből eredeztethető, majd az évszázadok során újabb és újabb változások következtek be a hadviselésben, ami újabb sportmozgások megjelenését eredményezte. Ugyanakkor ezek a sportmozgások segítették a katonák eredményes felkészítését, így visszahatva a hadviselésre.

$\mathrm{Az}$ ókori spártaiak nagy hangsúlyt fektettek a fiatalok testi nevelésére, harcra való felkészítésére. Folyamatosan gyakorolták a birkózás, a lándzsahajítás, az ökölvívás, vagy a kardvívás mozgásait, menetekkel, futásokkal, ügyességi gyakorlatokkal töltötték a felkészülési időt [4]. „Nincs szükségünk erösebb sáncra, mint fiaink testére."

Az ókori görög világban a sport szellemisége legerősebben az ókori olümpiai játékok formájában jelent meg. Itt már a sport céljává egyértelmüen a versengés vált a harcra való felkészüléssel szemben. Ugyanakkor az olimpiai versenyszámokat vizsgálva továbbra is megtalálhatók a harcból eredeztethető mozgásokra alapuló sportágak, mint a pankráció, a páncélban futás, vagy a pentatlon.

Az ókori római katonáknak képesnek kellett lenniük 20 mérföld menetelésre, felszerelésben futásra, úszásra, vagy dárdahajításra.

Természetesen az ókori történetírás nemcsak európai példákról számol be, de Egyiptomban és Kínában is fejlett sportkultúráról ad bizonyságot. 
A középkort a testkultúra fejlődése szempontjából nem tartjuk túlzottan eredményesnek, ugyanakkor a hét lovagi készséget vizsgálva bizonyítékát leljük annak, hogy ebben az időszakban is tudatosan készültek a fizikai igénybevételre (lovaglás, úszás, íjászat, vívás, vadászat, sakk, költészet/zene). A lovagi tornák pedig a versengés révén a sporttevékenységek közé is sorolhatók.

A napóleoni Franciaország jelentette fenyegetés hatására a XIX. század elején jelenik meg a német torna (turnverein = turnen-tornázni és verein-egyesület) a tanár és hazafi Friedrich Ludvig Jahn irányításával. A mozgalom célja a német fiatalok fizikai felkészítése a haza megvédésére, hatását a mai tornaversenyeken is megfigyelhetjük, hiszen olyan tornaszerek, mint a nyújtó, a korlát, a lólengésnél és az ugrásnál használt ló innen származik [5].

Ugyanebben az időben Svédországban Per Henrik Ling fejlesztett ki egy torna módszert, melynek orvosi, esztétikai, pedagógiai célja mellett katonai kategóriája is volt [6].

A Krími háború 1853-56. között zajlott és a brit hadvezetés számára újszerü tapasztalatot is hozott, miszerint katonái fizikai állapota meghatározó jelentőséggel bír a csaták kimenetelét illetően. Ennek is köszönhetö, hogy a brit katonai kiképzésben is egyre nagyobb hangsúlyt kap a testnevelés és a sport. A fejlődésre jótékonyan hatott az is, hogy számos német tornaszakember vándorolt el hazájából, akik közül többen segítették az angolok törekvéseit.

Amerikában a polgárháború (186165.) hozott hasonló tapasztalatokat, így ott is nagyobb teret kapott a fizikai felkészítés.

1896-ban, Athénban megrendezik az első Újkori Olimpiai Játékokat, ami elin- dítja a sport napjainkban is tartó sikertörténetét.

\section{A testnevelés és a sport jótékony hatása}

A rendszeres, az egyén számára optimális terhelést jelentő testmozgás jótékony hatású számos területen.

Élettani hatása megfigyelhető a mozgatórendszer tekintetében, ahol az izomfejlődésre, a csontsürüségre, az ízületek stabilitására és mozgékonyságára nézve előnyös. Az anyagcsereműködés területén elsősorban az egészséges testöszszetételt és a súlykontrollt, a szénhidrát anyagcserét és a koleszterinszintet befolyásolja. A szív-érrendszer vonatkozásában növeli a szív teljesítményét, az erek rugalmasságát és áteresztő képességét, valamint a kapillarizációt.

Mentális hatása a stresszterhelés kompenzációjában, a szorongás, az alvászavar enyhítésében, a kiegyensúlyozott és harmonikus élet fenntartásában, valamint az általános elégedettség, önbizalom és céltudatosság kialakításában jelentkezik. Érzelmi téren az öröm, a boldogság, a sikerélmény, a lelkesedés, vagy éppen a csalódottság és a kudarc megélésében és elfogadásában mutatkozik meg. „A sport megtanít becsületesen gyözni és méltósággal veszíteni. A sport tehát mindenre megtanit." (E. Hemingway)

A sportnak fontos társadalmi hatásokat is tulajdoníthatunk. Segít a közösségek összekovácsolásában, az egymáshoz tartozás megélésében, a bajtársiasság kialakításában, ami a fegyveres és rendvédelmi szervek életében kiemelt jelentőségü. Az egyén a közösség által jobban kiteljesedhet, az egymás iránti felelősség és figyelem is erősödik. Ez nem csak a sportolók között, de a szurkolók körében is erős hatást fejt ki. 
A sportnak természetesen gazdasági hatása is jelentős, de a jelenlegi téma szempontjából ennek értelmezése nem indokolt.

\section{A katonát érő fizikai terhelések}

A modern kor vívmányai ugyan számos területen leveszik az ember válláról a fizikai erőkifejtés terhét, azonban a katonákat még napjainkban is komoly fizikai terhelések érik. Feladatukat szabad vagy zárt térben, változatos terepen, gyakran városi környezetben, az időjárási szélsőségeknek kiszolgáltatva végzik. A feladatok során akadályokat küzdenek le, menetelnek, futnak, test-test elleni harcra kényszerülnek, amit a saját felszerelés súlya tovább nehezít.

Mindezért fontos a magas szintü fizikai teljesítő képesség, azon belül az aerob állóképesség, a kar, a törzs és a láb izom ereje és izomerő állóképessége, a mozgásgyorsaság, valamint a jó mozgáskoordináció (egyensúlyozó képesség, térbeli tájékozódás, ritmusképesség, testérzékelés, mozgástanulási képesség) és a hajlékonyság, ízületi mozgékonyság.

\section{A társadalom állapota}

A katonának beérkező fiatalok fizikai állapotától nagymértékben függ, hogy menynyi erőfeszítéssel lehet elérni a fenti képességszintet. Ezért fontos, hogy a felkészítő szakemberek tisztában legyenek a közel és távoli jövőben a katonának jelentkezők várható fizikai állapotával. Ehhez segítséget nyújthat a NETFIT (Nemzeti Egységes Tanulói Fittségi Teszt) adatbázis. Az alábbiakban a 12. évfolyamos (18 éves 15823 fö) fiatalok 2017. évi eredményei kerülnek elemzésre [7]. A legfontosabb fittségi mutatók a következő diagramokon kerülnek bemutatásra.
A NETFIT rendszerben a tanulókat különböző tesztekkel mérik fel, és három csoportba sorolják őket: Egészségzóna, Fejlesztés szükséges, Fokozott fejlesztés szükséges.

Először az általam vizsgált korcsoport testösszetételre és testzsírszázalékra vonatkozó adatait elemeztem (1. ábra). Ebből kitünik, hogy előbbi esetében minden negyedik-ötödik, utóbbi esetében minden harmadik tanuló az egészségzónán kívül esik, vagyis a túlsúly problémája már ebben a korban jelentkezik.

$\mathrm{Az}$ aerob állóképesség esetében sokkal rosszabb a helyzet, a fiúknál 50 \%-os, a lányoknál 35\%-os az egészségzónába tartozók aránya (2. ábra). Ez azért is elkeserítő, mert az állóképesség fejlesztés szempontjából a 12-16 éves kor döntő jelentőségü.

Az erő tesztek esetében jóval kedvezőbb a helyzet (3. ábra). Amennyiben a referencia értékeket helyesen határozták meg, és az eredmények megbízhatóak, akkor ezen a területen pozitív várakozásra van remény (az egyes tesztek felsorolása a I. táblázatban található).

Az elhízás már fiatal korban gondot okoz, amit alátámaszt Rurik vizsgálata is, aki 1988-2015. között tanulmányozta az elhízás alakulását a felnőtt lakosság körében az Országos Élelmezési és Táplálkozástudományi Intézet (OÉTI) és az ENSZ Egészségügyi Világszervezete (WHO) adatai alapján (4. ábra) [8]. A diagramon jól látható, hogy a túlsúlyos és az elhízott férfiak és nők száma 2015ben elérte az $50 \%$-ot.

Ennek okaiként elsősorban a helytelen táplálkozás és a mozgásszegény életmód nevezhető meg. Utóbbit támasztja alá az az adat, miszerint a magyar lakosság 53\%-a soha nem sportol, 24\%-a havonta háromszor és csak $23 \%$-a rendszeresen [9]. 


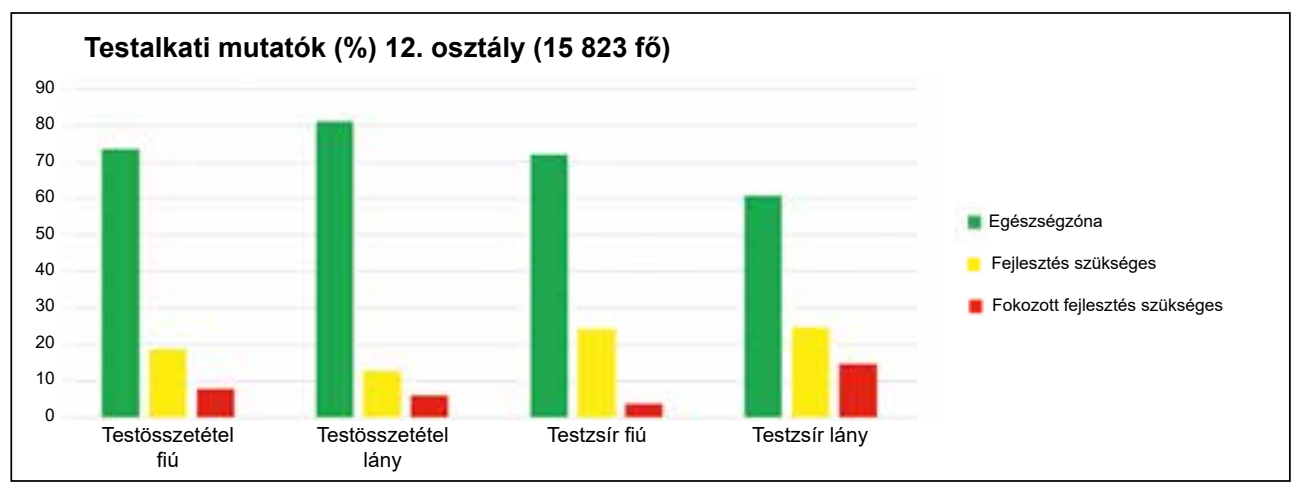

1. ábra. Testalkati mutatók

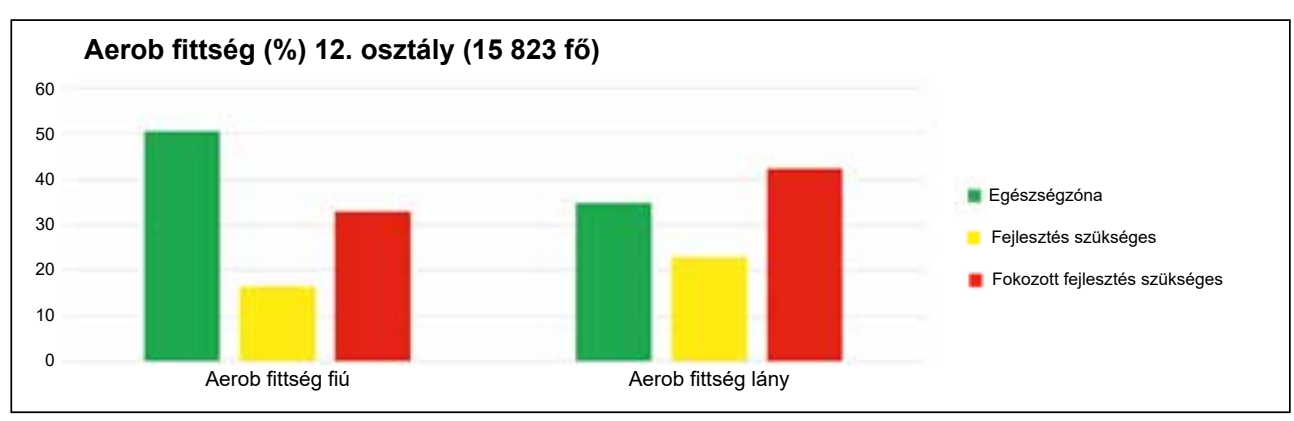

2. ábra. Aerob fittség

Törzs erő (\%) 12. osztály (15 823 fö)

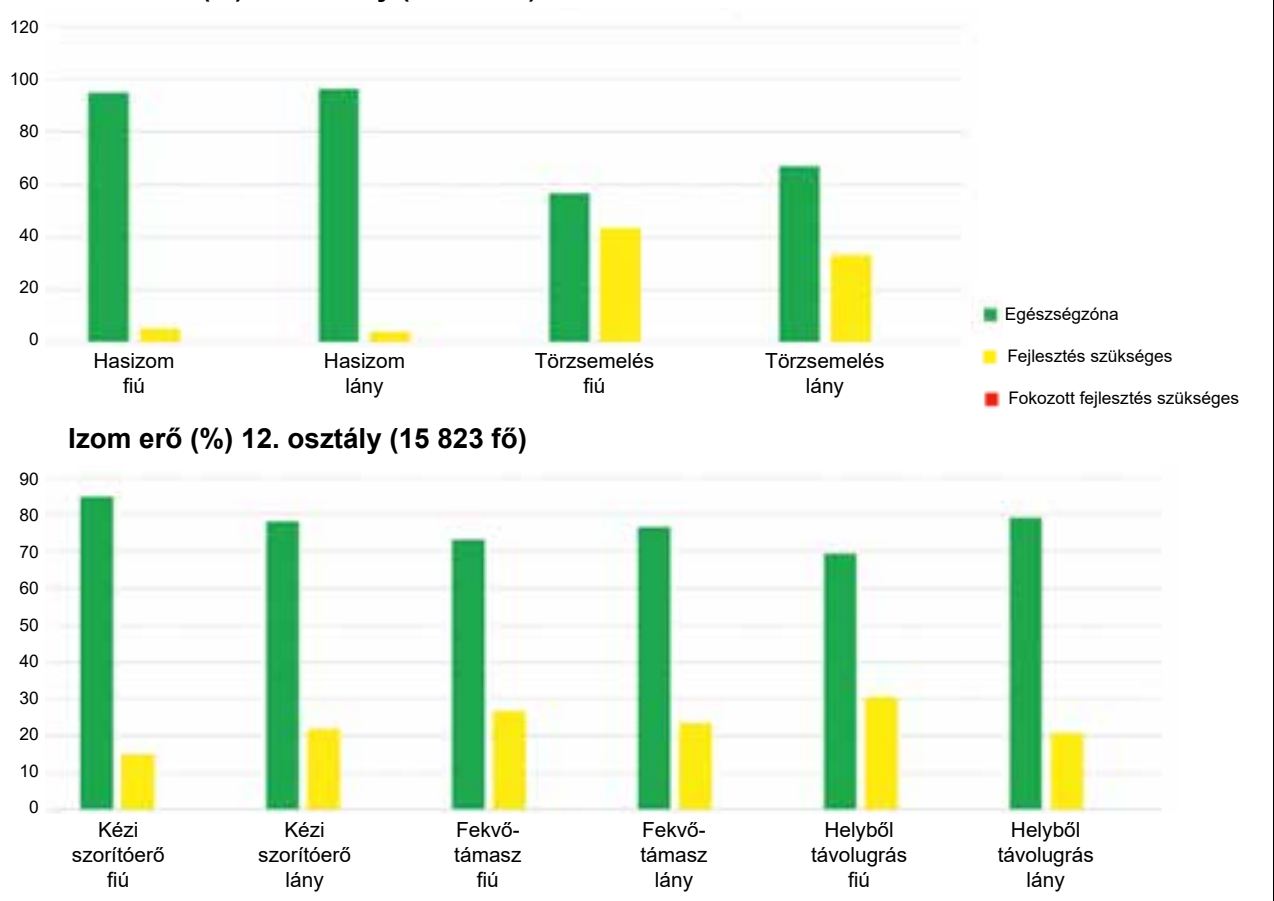

3. ábra. Erőtesztek ereményei 
I. táblázat. A NETFIT tesztek felsorolása

1. Testösszetétel és tápláltsági profil
testmagasság és testtömeg alapján
számított BMI érték
testzsírszázalék érték

2. Aerob fittségi profil 15 , vagy 20 méteres ingafutás teszt

3. Vázizomzat fittségi profil ütemezett hasizom teszt törzsemelés teszt ütemezett fekvőtámasz teszt kézi szorítóerő mérése helyből távolugrás teszt

4. Hajlékonysági profil hajlékonysági teszt

\section{A sport szerepe a fizikai felkészítésben}

A társadalom egészségi állapotáról alkotott szubjektív benyomások és a fenti tényszerü adatok alapján is megállapítható, hogy a katonák fizikai felkészítése napjainkban sokkal nagyobb hangsúlylyal esik latba, mivel a kiinduló érték (a bejövő állomány fizikai állapota) az elmúlt két évtizedben jelentősen romlott, miközben a kell érték (a katonai szolgálat során jelentkező fizikai terheléseknek megfelelő fizikai teljesítő képesség) számottevően nem változott.

A katonák felkészítése egy több öszszetevőből álló rendszer, amelynek középpontjában a katonai testnevelés kiképzési foglalkozásai állnak (elsősorban kondicionális képességfejlesztés, természetes és mesterséges akadályleküzdés, katonai közelharc, speciális kiképzés). E köré épül a reggeli testedzés, a délutáni tömegsport, a fizikai alkalmassági és a normakövetelményeknek való megfelelés, az önálló felkészülés, a rendszeres sporttevékenység és a rekreáció, valamint a sportversenyek.

A rendszer középpontjában álló kiképzési foglalkozások adják meg a felkészítés gerincét, jelölik ki a szakmai irányt, a többi felsorolt tevékenység biztosítja a képességek fejlődéséhez szükséges rendszerességet, a mozgások begyakorlását, készség szintre fejlesztését. Az alkalmassági követelmények jelentik a személyes ösztönzést, ami segíti a katonát a felkészülésben, a normakövetelmények pedig visszacsatolást biztosítanak a kiképzés eredményességére vonatkozóan.

Ebben az egységes rendszerben a sport jelenti azt az összekötő kapcsot,

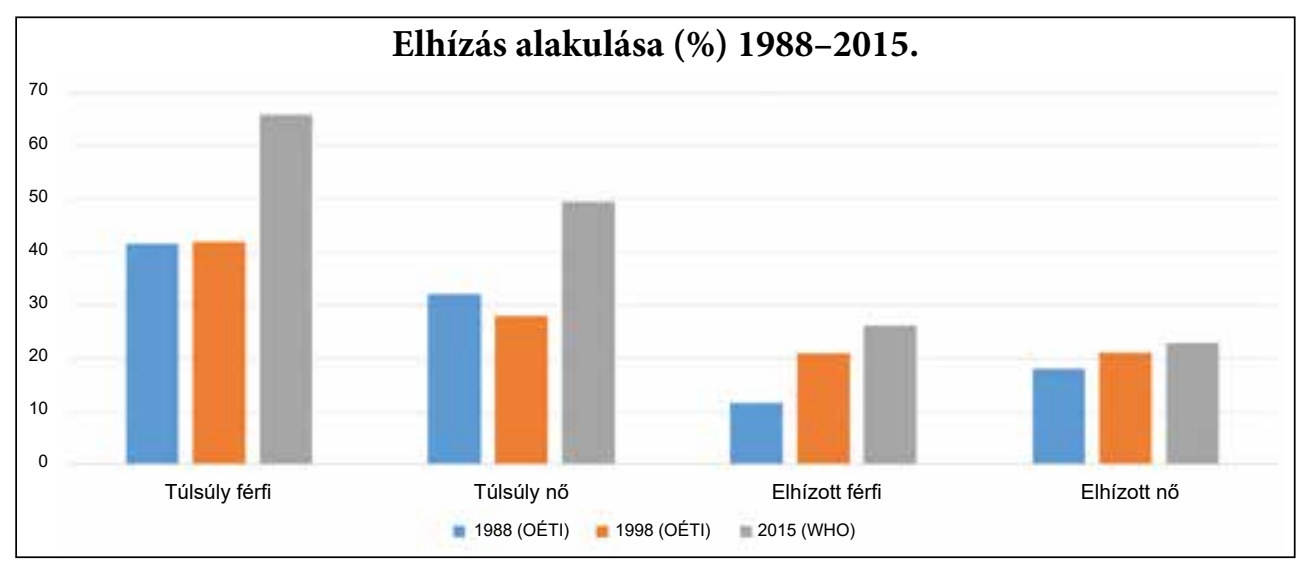

4. ábra. Az elhízás alakulása Magyarországon 1988-2015. között

(A szerző által készített ábra) [10] 


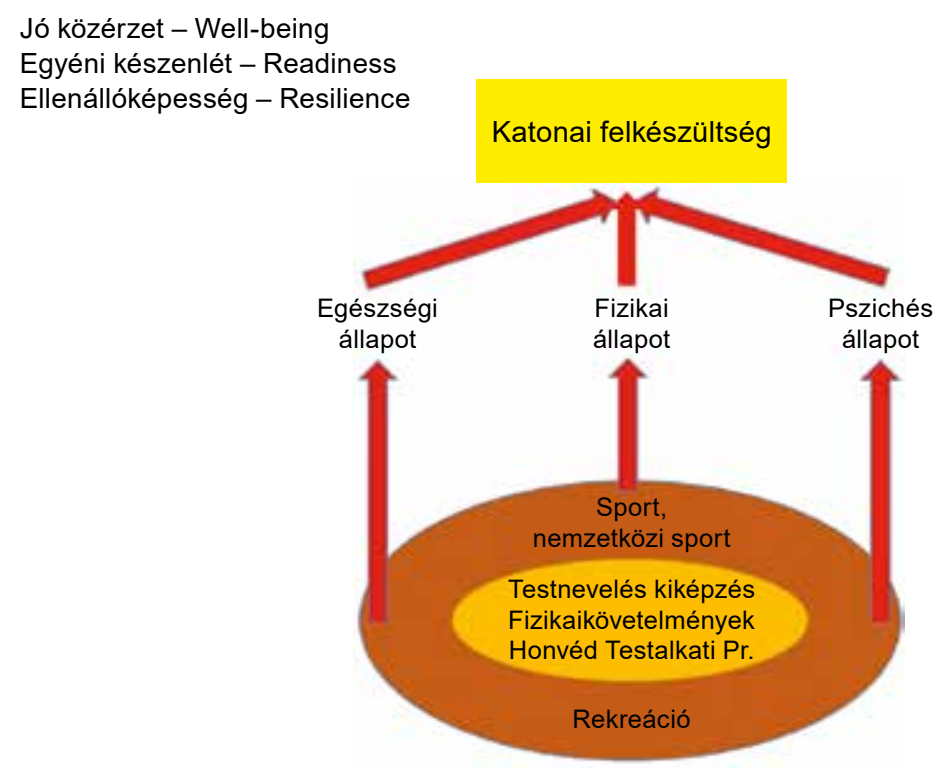

5. ábra. A testnevelés és a sport szerepe a katonák felkészítésében (A szerző saját ábrája)

ami a rendszer koherens működését biztosítja, legyen az versenysport, edzés, vagy rekreációs tevékenység (5. ábra).

A sport révén javul a katona egészségi, fizikai és mentális állapota, ami elengedhetetlen a komplett katonai felkészültség eléréséhez. Ezt a felkészültséget a jó közérzet (well-being), az egyéni készenlét (readiness) és az ellenálló képesség (resilience) jellemzik.

\section{Irodalom}

[1] Nádori L.: Edzés-versenyzés címszavakban 2005, 112 o., Ludovika Egyetemi Kiadó Nonpr. Kft, Budapest, ISBN: 9789639542976

[2] Kiss B, Sporttudományi és edzéselméleti alapismeretek. (Frenkl, 1978, 222.) http://psycho. unideb.hu/sport/fejezetek/kb_sporttudomanyi/_book/index.html,

[3] Európai Sport Charta és a Sport Etikai Kódex, 2001, 10 o. http://www.europatanacs.hu/ pdf/CM_Rec(1992)13.pdf, .
[4] Harmath Á: Miért volt legyőzhetetlen az ókori Spárta? 2017 https://jegyzettar.blog.hu/ 2017/08/21/miert_volt_legyozhetetlen_az_ okori_sparta

[5] EncyclopediaBritannica.https://www.britannica.com/sports/turnverein

[6] Honfi L: A sporttorna elmélete és gyakorlata. 2011. http://tamop412a.ttk.pte.hu/TSI/ Honfi-Szatmari\%20-\%20A\%20sporttorna\%20elmelete\%20es\%20gyakorlata/sporttorna.html\#d5e54

[7] Kaj M: A magyar 10-18 éves tanulók egészségközpontú fittségi állapota. 2018. http://www. mdsz.hu/wp-content/uploads/2018/02/ NETFIT_jelentes_2016_2017-1.pdf

[8] Rurik I: Elhízó Magyarország. A túlsúly és az elhízás trendje és prevalenciája Magyarországon 2015. Orvosi Hetilap, 2016. 12481255.https://akademiai.com/doi/pdf/10.1556/ 650.2016.30389 DOI: $10.1556 / 650.2016 .30389$

[9] Pavlik G: A rendszeres fizikai aktivitás szerepe betegségek megelőzésében, az egészség megőrzésében. Egészségtudomány. 2015. 2. sz. 11-26. http://egeszsegtudomany.higienikus. hu/cikk/2015-2/Pavlik.pdf 


\section{Col. Z. Eleki PhD}

\section{The role of the physical education and sport in the military training}

In History, the role of the sport in military training is indisputable. The surviving capability of a well-trained soldier was (and is) much stronger than others, besides the world sport also developed, thanks to the military application. New sports were born, mainly among the team sports. The sport also has a role in the health care, the team building, the stress coping and the recruitment.

Due to the technical development, the daily physical activity and the physical fitness level of the society is declining nowadays. That phenomena makes the military training more difficult. In the Hungarian Defence Forces, the physical training is a complex system, including the fitness test, the military physical training, the competitive and recreational sport events and the Soldier Body Composition Program.

Using an effective physical education and sport program, we can improve the physical fitness and health of our Armed Forces personnel, introduce the greatness of the military servicemen, and support the recruitment system.

Key-words: physical education, sport, military training, health care, team building

Dr. Eleki Zoltán ezds., $P h D$ 2000 Szentendre, Dózsa Gy. út 